University of Nebraska - Lincoln

DigitalCommons@University of Nebraska - Lincoln

The Oldest Post-Truth? The Rise of Antisemitism in the United States and Beyond

Gerald Steinacher

Follow this and additional works at: https://digitalcommons.unl.edu/historyfacpub

Part of the American Popular Culture Commons, European History Commons, History of Religion Commons, Holocaust and Genocide Studies Commons, Political History Commons, and the United States History Commons

This Article is brought to you for free and open access by the History, Department of at DigitalCommons@University of Nebraska - Lincoln. It has been accepted for inclusion in Faculty Publications, Department of History by an authorized administrator of DigitalCommons@University of Nebraska - Lincoln. 


\title{
The Oldest Post-Truth? The Rise of Antisemitism in the United States and Beyond
}

\author{
Gerald J. Steinacher \\ University of Nebraska-Lincoln
}

The very concept of objective truth is fading out of the world. Lies will pass into history.

George Orwell

\section{Introduction}

Antisemitism, the negative stereotyping and hatred of Jews, has overshadowed Western history for 2000 years. In the 2oth century, antisemitism led to the Shoah, the systematic state-sponsored murder of 6 million Jews by Nazi Germany and its allies. In recent decades, antisemitism diminished significantly in the Western world, and there was hope that this plague would soon be consigned to the past. On the contrary, the past few years have witnessed a drastic increase of antisemitism in Western societies, often paired with far-right activism, racism, and xenophobia. In 2017 in Charlottesville, there were hundreds of marchers giving Nazi salutes, waving swastika flags, and shouting "white lives matter!," "Sieg Heil,” and "Jews will not replace US." One

Published as Chapter 7 in History in a Post-Truth World: Theory and Praxis, edited by Marius Gudonis and Benjamin T. Jones. Routledge/Taylor \& Francis Group, pp 121-141.

Copyright (C) 2021 Taylor \& Francis. Used by permission.

doi:10.32873/unl.dc.oth.010 
of the white nationalists murdered counter-protester Heather Heyer and injured many others. One year later, in October 2018, an antisemite attacked the Tree of Life synagogue in Pittsburgh and murdered 11 people. This was the bloodiest antisemitic motivated attack in the history of the United States. In 2019, there was a subsequent mass shooting targeting the Chabad of Poway synagogue in California, which left one dead and three wounded. The attacker was a declared white supremacist and an antisemite.

Research data show a strong rise of antisemitism in the United States in recent years. According to the Anti-Defamation League (ADL), the number of antisemitic attacks in the United States surged by $57 \%$ in 2017. With a total of 1986 incidents reported that year, this number represented the biggest single-year increase in reported anti-Jewish hate since the ADL began gathering such data 40 years ago. University campuses are not safe spaces either: The ADL reported 204 incidents on US college campuses in 2017 , an $89 \%$ increase from the previous year. $^{2}$

Although each of these incidents is deeply troubling, let us briefly look at a few of the most recent. In July 2018, hundreds of Omaha residents were troubled over Nazi literature left in several Little Free Libraries. This hate material included reprints of children's books from the Nazi era that promoted antisemitism. Around the same time, posters showed up on poles in Omaha neighborhoods calling for the local citizenship to denounce illegal immigrants to the authorities. In July 2018, a swastika was chemically burned into the grass at War Memorial Park in Omaha. ${ }^{3}$ University campuses around the country registered a significant rise in attacks on Jews. A Holocaust scholar at Columbia University found her office walls painted with two huge red swastikas and a slur, "Yid" (Jew). At Duke University, a swastika was smeared over a monument honoring the victims of the Pittsburgh synagogue massacre. A Jewish fraternity at Pennsylvania State University was vandalized and its menorah stolen just weeks after the Pittsburgh attack. At a number of universities in California and elsewhere, flyers were posted holding Jews responsible for the sexual abuse allegations against Justice Brett Kavanaugh. During the most recent US presidential campaign, rising antisemitic sentiment became detectible in many places, including the University of Nebraska. In December of 2016, local newspapers reported on an incident at the University of 
Nebraska-Omaha. Someone had carved a swastika into a bathroom wall along with the messages "Make America great again" and "Kikes to the gas!" - "Kikes" being a racial slur for Jews. ${ }^{4}$

In Europe and the United States, the rise of antisemitism was and is intimately connected with white nationalism. White nationalism is a widely used euphemism for white supremacy. Promoters of this ideology often embrace racism (ideas of nature-given racial hierarchy and the belief of "white" Christian European dominance), ethnic nationalism (nationality/citizenship is bound to ethnicity), and antisemitism (hatred of Jews). The alternative right (alt-right) is a loose coalition of more or less extreme right-wing groups that share some or all of the views just mentioned. The roots of racism and bigotry go far back to the beginnings of the European colonization of what is now called the United States. The genocide of native peoples, slavery, lynching, eugenics, and discriminatory immigration laws are just a few examples of that. And violence was always in the mix. In recent years, the majority of domestic terrorism acts were committed by white supremacists. The most recent occurred in August 2019 with mass shootings in Gilroy (California), Dayton (Ohio), and El Paso (Texas). The shooter in El Paso, who killed 22 people with an AK-47-style rifle, targeted explicitly Mexicans and other Latinos in a shopping mall close to the Mexican border. The "manifesto" that he posted just before the attack is full of hate language against immigrants, referring to an "invasion." He also stated that people should not blame US President Donald Trump for the blood bath. The Gilroy shooter seemed to have shared antisemitic, neo-Nazi material on the Internet. ${ }^{5}$ In October 2019, during the high Jewish holiday of Yom Kippur, a heavily armed man attacked a synagogue in the German town of Halle. He killed two bystanders near the temple and confessed later that he was motivated by antisemitic and extremist right-wing views.

In the aftermath of El Paso, President Trump condemned "racism, bigotry, and white supremacy." In the same speech, he called for immigration reform. Trump rarely takes a clear stance against white supremacy - quite the opposite, in fact. ${ }^{6}$ After the violent neo-Nazi rally in Charlottesville, President Trump infamously stated that there were fine people on "both sides." Historian Deborah Lipstadt asks, "Why was Trump suggesting that there was moral equivalency between racists and the counterdemonstrators? ... Only one side carried 
Confederate flags and flags with Nazi-like and swastika-inspired symbols. Only one side shouted racist and antisemitic insults." 7 And it was a white supremacist who murdered counter-protester Heather Heyer. Trump's lax reaction to antisemitism is somewhat surprising given that some of his closest family members are Jewish. Trump's son-inlaw is a practicing Jew, and his daughter has converted to Judaism. Trump obviously tries hard not to alienate racists, white nationalists, and antisemites, because they remain strong among his supporters.

\section{Antisemitism and Post-Truth}

Antisemitism is not easy to define, and there are many ways to focus on various elements constituting it. The ADL summarizes it as follows:

The belief or behavior hostile toward Jews just because they are Jewish. It may take the form of religious teachings that proclaim the inferiority of Jews, for instance, or political efforts to isolate, oppress, or otherwise injure them. It may also include prejudiced or stereotyped views about Jews. ${ }^{8}$

Although the ADL definition of antisemitism is correct, hatred may not be the only factor at play. But other definitions view antisemitism as a cold way of thinking about the world rather than raw emotion. This latter view is probably most famously represented by the Israeli philosopher Yehezkel Kaufmann, who in 1936 wrote that

It is customary to define the word "anti-Semitism" as "hatred of Jews," but this definition is not accurate. Anti-Semitism is not Jew-hatred as such. It is the rationalizations men develop who are hostile to the Jew, to justify their hostility. Antisemitism is, thus, not the emotion, but the ideas revolving around it, in some cases even developing into a kind of "scientific system." 9

In the context of discussions about post-truth, antisemitism is very relevant. It is not just about lies and hatred for political or religious gain; rather, sophisticated long-standing conspiracy theories lie at 
the heart of it. Antisemitism is more than a lie, it is a narrative of alternative truth. An argument can be made that antisemitism is one of the oldest and continually existing examples of post-truth in history. It is also one of the most enduring and hateful. Historian Dina Porat summarized it concisely: "Denying, distorting, and especially inverting have been techniques of antisemitism since antiquity, and have aimed at creating images of Jews that are the opposite of what is found in reality." 10

When studying antisemitism, one can learn little - if anything at all - about Jews. But we learn a lot about the hate fantasies and negative stereotypes of non-Jews about Jews. Antisemitism operates by using fictional allegations, which is one reason why fighting it with factual arguments is often so difficult. Historian Doris Bergen highlights this point when she writes, "Prejudices are habits of thought, they are not reasoned responses to objective realities." ${ }^{11}$ Post-truth works along the same lines.

"It's official: Truth is dead. Facts are passé," The Washington Post wrote in November 2016 in response to the decision by Oxford Dictionaries to choose "post-truth" as the word of the year. ${ }^{12}$ The dictionary defines "post-truth" as "relating to or denoting circumstances in which objective facts are less influential in shaping public opinion than appeals to emotion and personal belief." "Post-truth" or the other fashionable terms like "alternate facts" or "fake news" were traditionally often referred to as fabrications or lies. But the Oxford definition of post-truth puts its emphasis not on lying but on "emotion and personal belief." Post-truth is much more than a fashionable name for "lying." Some academics do indeed think of post-truth as lying, but others have explicitly stated that post-truth is not the same. The French philosopher Mazarine Pingeot, for example, says that "the danger of post-truth is not the lie, which in itself may even constitute a form of freedom from factuality, but indifference to the distinction between the lie and the truth." 13 The post-truth decision by Oxford happened shortly after the US presidential election in 2016 and the Brexit vote in the United Kingdom. These events illustrate a perceived crisis of truth in Western democracies. Political leaders and particularly those from populist parties often have a suspect relationship with truth: They feel entitled both to their opinions and to their own facts. The philosopher Immanuel Kant defined enlightenment as humankind's 
"release from [our] self-incurred tutelage." Thus, according to Kant, knowledge about the true nature of the world is achieved through reason and courage. In other words, people should use their mind by thinking critically. Post-truth operates not with facts and reason but with emotions and personal beliefs.

This chapter will make two major arguments:

1. Post-truth is not new: antisemitism, especially when it manifests itself in Holocaust denial and Jewish global conspiracy, has exhibited the typical characteristics of post-truth discourse for a long time.

2. Recently, many far-right groups have attempted to make their brand more palatable by communicating a seemingly pro-Israel stance.

\section{A Short History of Antisemitism}

In Antisemitism: Here and Now, Deborah Lipstadt, one of the most renowned scholars on this topic, writes,

As horrific as the Holocaust was, it is firmly in the past. When I write about it, I am writing about what was. Though I remain horrified by what happened, it is history. Contemporary antisemitism is not. It is about the present. It is what many people are doing, saying and facing now. That gave this subject [of antisemitism] an immediacy that no historical act possesses. ${ }^{14}$

Given recent events, Lipstadt's concerns do not need to be explained further. But what is it, and why does it keep coming back? Here is not the space to discuss in detail the long history of antisemitism, but some basic background is required.

In the year $70 \mathrm{CE}$, the Romans destroyed the temple in Jerusalem, which had been the religious and political center of Judaism for centuries. This event meant the end of the Jewish uprising and the eventual dispersion of most survivors all over the Roman Empire, marking the beginning of the Jewish Diaspora, life as a religious minority 
without a state. Around that time, small groups of Jews formed communities. They believed in Jesus of Nazareth as the long-expected prophetic messiah. These Judeo-Christians were initially a small sect, but they quickly grew in number because they were also missionizing among gentiles. Around the year 380, Christianity became the state religion of the Roman Empire. While non-Christians were persecuted and killed, the Jews remained the only religious minority tolerated (if only barely) in the Christian world. St. Augustine, an influential theologian of the early Church, laid the basis for a widely shared practice. He argued that Jews should be despised and kept in misery, but not killed. They should not be killed, he reasoned, because there was hope for their ultimate conversion. As a result, Jews were often segregated into ghettos, banned from many professions and from owning land. The Middle Ages saw the creation of vicious allegations against Jews, some of which are still present. Church leaders accused the Jews of being in league with Satan and for conspiring against Christians. Unsurprisingly, Jews soon became scapegoats for all ills, all things that could not easily be explained and were therefore particularly frightening. In the context of post-truth, four manifestations of historical antisemitism are especially relevant to the subject of this paper: blood libel, accusations of host desecration, "Jewish global conspiracy," and Holocaust denial. These are all fabrications almost immune from facts and can therefore be argued to be post-truth. Jews were accused of kidnapping Christian children (mainly boys), slaughtering them in religious rituals during Passover, and drinking or eating their blood. Jews were accused of stealing or buying hosts and then sticking knives and hot nails into them. In Catholic belief, the host literally represents the body of Christ. In other words, Jews were accused of mimicking and "re-enacting" the crucifixion of Jesus. What followed such unfounded and horrible allegations were often massacres (pogroms) against the nearest Jewish population. The last massacre against Jews, based on false "blood libel" charges, occurred in Kielce (Poland) in 1946, when 42 Jews were murdered.

In Western Europe from the Middle Ages to the 19th century, Jews constituted only about $1 \%-2 \%$ of the total population. In other words, Jews were members of a tiny religious minority. In the United States today, Jews account for less than $2 \%$ of the population. With the Enlightenment, Jews were given rights of citizenship and allowed to leave 
their ghettos (though not until 1917 in Russia). However, religious antisemitism did not disappear but was instead flanked by a secular version of antisemitism. Against the background of pseudoscientific theories about race, Jews were seen not merely as adherents of a different religion but as a separate "race." For the "modern" antisemite, conversion or assimilation was not an option that would solve "the Jewish question."15

The term "antisemitism" was eventually coined in 1870 by the German journalist Wilhelm Marr (1819-1904) as the "scientific" term for the (secular) "theories" about the nature and role of Jews in society and history. To this day, antisemitism contains a mix of religious, racist, and political charges and arguments. ${ }^{16}$ With European immigration, antisemitism came to the Americas, reflecting many of the centuries-old stereotypes and accusations common from the "old world," including the "blood libel." One famous US case was that of Leo Frank, who was lynched in Georgia in 1915 for allegedly murdering a Christian girl. One long-lived conspiracy theory claims that Jewry is plotting to take over the world and dominate Christians.

\section{The Jewish World Conspiracy}

As pointed out earlier, the idea of Jews being a malevolent force conspiring to control the world is old and rooted in Christian antisemitism (also referred to as anti-Judaism). One of the most widely distributed antisemitic lies is based on the so-called Protocols of the Elders of Zion, an antisemitic forgery put together by the Russian secret police and first printed in 1903/1905. ${ }^{17}$ It recounts the "minutes" of a series of alleged meetings of anonymous Jewish leaders and is set around the first Zionist congress in Basel (Switzerland) in 1897. These Jewish leaders were allegedly plotting to bring Christians under their worldwide rule. To achieve that goal, the conspiracy theory states that Jews undermine Christian societies with ideas of socialism and liberalism. The forgers did not invest much time: they mostly plagiarized from a number of French and German books, just switching the main characters. Despite being repeatedly exposed as a complete fabrication, it was quickly translated into all major world languages and became 
classic antisemitic propaganda. In the United States, it was none other than automobile pioneer Henry Ford who published the Protocols in his newspaper, the Dearborn Independent, as a serial starting in 1920. Under the title "The International Jew: The World's Problem," Ford accused Jews of controlling the media and financial systems in order to enslave (white Christian) Americans. ${ }^{18}$ Hitler admired Ford, and the Nazi government awarded the prominent American the highest order for a non-German. He was a US hero to many and at the same time a significant force for antisemitism in the United States.

In October 2018, flyers were posted at a number of universities in California and elsewhere holding Jews responsible for the sexual abuse accusations against Justice Brett Kavanaugh. Politicians of Jewish background such as US Senators Dianne Feinstein and Chuck Schumer were shown as caricatures standing around Kavanaugh and rubbing their hands. They were signified as Jews with a large Star of David on their foreheads. The flyer states, "every time some antiwhite, anti-American, anti-freedom event takes place, you look at it, and it's Jews behind it." ${ }^{19}$ As absurd as the whole thing looks and is, there is an underlying history and message behind these antisemitic themes and depictions of Jews.

The aforementioned antisemitic flyer distributed in California again reflects this entrenched belief and applies it to current issues. Jews are depicted as plotting against Americans, and the Christian Kavanaugh is their latest "victim." No evidence is provided to support these absurd claims. For the antisemites, it was enough "evidence" that there are critics of Kavanaugh among Democrats who have a Jewish background. The Jewish conspiracy is accepted as a fact and can be applied to any current issue. These views are also dangerous because they often lead to violence and murder. In April 2019, a man with an assault-style rifle killed one worshipper and wounded three others in the Chabad of Poway synagogue in California. The attacker, a declared white supremacist, wrote in an open letter that he was fighting back against the Jews because they were plotting a genocide of the white European race. In these antisemitic fantasies, Jews are not conspiring with Satan anymore, but they still want to harm gentiles and bring evil to the world. 


\section{The Jewish Bogeyman}

Like antisemites of any era, Ford actively sought the personification of the Jewish enemy. He found it in Aaron Sapiro, a Jewish lawyer and farmer's union activist. When Sapiro sued Ford for libel, hate speech itself was on trial. Ford used his influence to try to demonize Sapiro. But Sapiro was not intimidated, and as a result, Ford eventually gave in and settled out of court. In 1927, Ford closed the Dearborn Independent, shuttering its antisemitic crusade. ${ }^{20}$ Nowadays, antisemites pursue a similar strategy. Prominent community leaders of Jewish background are demonized and presented as "evidence" for the "Jewish world conspiracy." Well-known Hungarian-American philanthropist George Soros is the "all-powerful" Jewish bogeyman for modern antisemites. The current right-wing government in Hungary under Prime Minister Viktor Orban uses "international Jew" Soros repeatedly as a hated scapegoat for all kinds of problems (especially regarding issues of immigration): "It shows the enduring power of the myth of the omnipresent, omnipotent Jew on the far-right of European politics," the Israeli newspaper Haaretz wrote. ${ }^{21}$ Protester signs in Hungary show Soros's image with devil horns added to it, and billboards in Budapest read "Stop Soros."

But in the United States too, Soros became a target for haters. In 2018, President Trump and his allies insinuated that Soros was the financier of the migrant "caravan" from Central America. For believers of this conspiracy theory, Soros's (and the Jews') "masterplan" involves replacing European-Americans with non-white people. Certain alt-right communities even believe that Jews should be held to account for larger shifts in demography, including interracial marriage, feminism, and the emergence of the larger queer community. ${ }^{22}$ This "replacement" conspiracy theory is a good case for a post-truth story. It shows that post-truth is not just about lies but about rather sophisticated alternative "explanations" of phenomena. In July 2019, the White House invited conservative and right-wing journalists for a social media summit. Among the invitees was the author of an antisemitic cartoon depicting Soros as an instrument of the Rothschilds who was also pulling the strings of the "puppets" of National Security Adviser H.R. McMaster and retired general David Petraeus, who had both fallen out of favor with the president. ${ }^{23}$ The image of the Jewish 
"puppet master" pulling the strings is an old cliché, and the Rothschilds were blamed as the masterminds of alleged Jewish conspiracies in previous centuries. ${ }^{24}$ It comes as no surprise that Soros is also a popular target of Breitbart News. The right-wing outlet became widely known during the tenure of its former executive and former Trump strategist Steve Bannon. ${ }^{25}$

Soros is not only a businessperson but also the founder of the Open Society Foundation and as such an admirer of Austrian-British philosopher Karl (Charles) Popper, who argued for an open society, where everyone is valued, where critical thinking is encouraged, and where the rule of law is respected. Its enemies have a different vision of society: not everyone is valued, critical thinking is hindered, and the rule of law is not respected. ${ }^{26}$ Soros adds to Popper's concept by stressing the importance of truth and facts in an open society. Free elections or the freedom of the press are under siege if facts are constantly and systematically manipulated or do not matter at all. Soros concludes that with the end of truth comes the end of democracy. It comes as little surprise that Soros and his brainchild, the Central European University in Budapest, are under intense attack by right-wing politicians in Europe and the United States. As of 2019, the Central European University in Budapest was forced to leave that city because of the massive pressure from the current right-wing Hungarian government. Charles Popper stated that democracy is a great experiment with flaws and that it is impossible to always foresee what can undermine it. Importantly, we now witness "the first expulsion of a university in the European Union," as the Austrian liberal newspaper Der Standard put it. ${ }^{27}$ This is a bad sign for Europe's state of democracy and a bad sign for European Jews.

\section{Holocaust Denial}

The 2016 film Denial received a lot of international attention. The storyline is based on the trial between US historian Deborah Lipstadt and the British Holocaust denier David Irving. On the surface, this was a defamation/libel trial only. But much more was at stake because crucial facts on the murder of 6 million European Jews were challenged by deniers. In other words, truth itself was put on trial when Irving 
sued Lipstadt in a British court. In 1994, Lipstadt, a professor at Emory College in Atlanta, published the book Denying the Holocaust: The Growing Assault on Truth and Memory, in which she labelled Irving a Holocaust denier because he questioned numbers and methods of the genocide. Irving, who had a certain prominence as a Hitler biographer even outside of right-wing circles, sued Lipstadt for libel. ${ }^{28}$ The film dramatizes the trial, which went on for four years and ended in 2000 with Lipstadt winning. The agreement on certain basic facts of the present and the past is a precondition for a functioning society. Everyone is entitled to their opinion but not entitled to their own facts. Lipstadt points out that Holocaust denial is similar to denying other central historical events. For her, the whole trial initially felt unreal: "That would be the equivalent of the scholar of ancient Rome debating whether the Roman empire ever existed or the French historian proving that there really was a French Revolution." ${ }^{29}$ Holocaust denial is not based on facts but is, instead, irrational.

It should come as no surprise that Holocaust denial is deeply rooted in antisemitism. Dina Porat, a prominent Israeli Holocaust scholar, wrote on the underlying motivation of deniers:

It is indeed denial in and of itself, in various forms and degrees, that they want to achieve, or is it actually the twisting and inversion of the image of the Jew, so that it might continue to fulfill the task it has always fulfilled: to serve as the dark negative counter-mirror of one's own positive image, regardless of reality?30

For Porat, Holocaust denial is usually also a part of antisemitism. In addition, it is also an important ingredient of a white supremacist, racist, and neo-fascist working agenda. ${ }^{31}$ David Duke, the former imperial wizard of the Ku Klux Klan is also a Holocaust denier. ${ }^{32}$ It is not surprising that during the "Unite the Right" rally in Charlottesville, of which Duke was one of the organizers, antisemitism featured prominently. Since the 1970s, Holocaust denial is on the rise, and today it is no longer limited to fringe groups on the extreme right. Lipstadt points out that nationalists as well as racists and antisemites are confronted with a problem: Since World War II, "Nazi” has been a bad word, particularly because of the unprecedented crimes they 
committed.33 There is now a tendency among right wingers and white nationalists to distance themselves from Hitler and the Holocaust so as to make far-right ideologies more acceptable to mainstream society.

One example is demonstrated in events connected to the conservative student organization Turning Point USA (TPUSA). Founded in 2012, TPUSA's stated goal is to appeal to young conservatives, especially on college campuses, to push back against liberal views. In December 2017, the New Yorker reported that this conservative nonprofit was accused of "racial bias and illegal campaign activity." 34 In February 2019, a video became public that showed the organization's communications director, Candace Owens, talking about Hitler and nationalism: "If Hitler just wanted to make Germany great and have things run well - okay, fine. The problem is that he ... had dreams outside of Germany [and] wanted to globalize." Owens's statement from a December 2018 event in London drew a lot of attention and criticism. In a congressional hearing about the rise of white nationalism, Owens, who is African American, defended and clarified her statement by saying that she tried to separate the term "nationalist" from its associations with Hitler and the Nazis, adding, "He wasn't a nationalist .... He was a homicidal, psychotic maniac." 35 But Owens got the facts wrong. The first concentration camps in Germany were established in 1933, only weeks after the Nazis took power. So, the "problem" with the Nazis was not "globalization" but rather the inherent racism and violence.

When right-wing populist governments in various countries reference the Holocaust, they work hard to make it fit into their narrative of the past. One case is Poland, where the nationalist government in 2018 passed a controversial law that would punish anyone with up to three years in prison who blamed the "Polish nation" for the Holocaust. Following an international outcry, the law was amended, making it a civil rather than a criminal offence. Poland suffered terribly under the Nazi occupation, but there is also the fact that many Poles were involved in persecuting Jews during the Holocaust. As is so often the case, this law is a matter of interpretation, and it remains to be seen whether independent historians seeking the truth will be punished by it. ${ }^{36}$ In Hungary and other Central and Eastern European countries, there is a tendency to lump together the crimes of the Nazis and Communists and to present themselves as victims (and victims 
only) of both dictatorships. ${ }^{37}$ The Holocaust happened, but the perpetrators remain nameless and abstract. Another relatively common phenomenon in some Eastern European countries is the idealizing of Nazi collaborators as "anticommunist freedom fighters." ${ }^{38}$ Far-right political parties in Germany (especially in the Eastern states) emphasize the suffering and the victim status of the German civilian population during World War II. Allied bombing raids (Dresden) and the brutal expulsion of millions from eastern parts of prewar Germany are central elements of this narrative. Under the motto "others suffered too," this revisionist view has the tendency to downplay guilt and responsibility and take away the uniqueness of the Holocaust. 39

The passage of time seems to make it easier for deniers and minimizers. We are now at the point when the last survivors are quickly passing away. It is only a matter of time before there are no more Holocaust survivors or other witnesses among us. Without contemporary witnesses of these events, contemporary history will become history. In the words of Lipstadt, "For them [the future generations] it will be part of the distant past and consequently, more susceptible to revision and denial." ${ }^{\circ}$ With the distance of time, there is the potential for the Nazi past to become more normalized. Gavriel Rosenfeld gets right to the point when he states that

Overturning the sense of the past's exceptionality is one of several goals that define the broader phenomena of normalisation. Normalisation is a relatively new concept that historians and other scholars have increasingly employed to understand how and why perceptions of the past shift over time. ${ }^{41}$

Perceptions of the Holocaust are no exceptions.

Popular works of fiction play an increasingly important role in our perception of the past. The alternate history television series The Man in the High Castle presents a world in which the Nazis won and shared control of the United States with the Japanese. In Timur Vermes's bestselling book Look Who's Back, Hitler returns from the dead to present-day Berlin..$^{2}$ With initially no memory of his previous life, Hitler goes on to become a successful comedian. But soon enough, his "role" is being himself. In a novel by British author C.J. Sansom, Dominion, Great Britain is reduced to a Nazi satellite state. These books 
and films often come with a warning of a possible re-emergence of fascism with a contemporary appearance. These fictional narratives and representations of historical events in new form have an impact on a wide audience. Most people get their knowledge about the Holocaust from films, documentaries, and even more so from (semi-)fictional movies and novels. For nonexperts, it is often difficult to put these narratives into a wider historical context. But historians are often left to react to those popular cultural narratives of a past instead of shaping them. Alvin H. Rosenfeld argues that the historian's role and even memory itself is supplanted by the arbiters of popular culture. ${ }^{43}$ In addition, Nazi history and the Holocaust are frequently material for science fiction novels, horror movies, video games, and reenactment games. The difference between historical facts and fictional/semi-fictional representations start to blur. These relatively new forms of "storytelling" are largely unchartered territories in regard to Holocaust memory, and it remains to be seen what long-term consequences they will have. ${ }^{44}$

To be sure, Holocaust deniers are a minority in the Americas and Europe. In the past few decades, remembering the Holocaust and drawing moral lessons from it have been central elements in Western democracies. ${ }^{45}$ Holocaust denial is punishable by law in over 20 countries, Germany being one of the strictest countries enforcing them. There is a growing number of memorials, museums, and research centers dedicated to the history of the Nazi regime and the Shoah. Popes John Paul II and Benedict XVI visited Israel's Holocaust Museum and memorial at Yad Vashem and honored the victims. ${ }^{46}$ Holocaust education is now required in more and more states in the United States (as of 2019, 12 states have already enacted the necessary legislation, and others are currently working on it). The bipartisan consensus on the importance of Holocaust education is a bright light among the troubling evidence of rising antisemitism in our midst. In an increasingly polarized society, common ground about how to commemorate the Holocaust and what to learn from it is anything other than taken for granted. What makes things even more complicated is antisemitism hidden as a critique of Israel, both from the political right and from the political left. 


\section{"Pro-Israel and Antisemitic" Dilemma}

Theodor Herzl of Vienna, one of the fathers of modern political Zionism, hoped that a Jewish state would end antisemitism. Sadly, he was wrong. The foundation of the state of Israel in 1948 merely changed certain aspects of antisemitism. In recent years, critiques of Israel with more antisemitic or less antisemitic undertones have occurred frequently on both the political (far) right and the political (far) left. Since the 1960s, European and American leftists have often sided with the Palestinians and supported their "struggle for liberation." In recent years, the best-known leftist group attacking Israel has been BDS, which stands for Boycott, Divestment, and Sanctions. BDS criticizes Israel for its current politics regarding the Palestinians. Of course, not every critique of Israel is automatically antisemitic. Every government can and should be criticized if democratic standards are transgressed or if human rights violations occur. But the criticisms and demands by BDS go far beyond that by putting in question the very existence of Israel. 47 With such demands, the BDS is clearly antisemitic in its nature and stated goals. Also, antisemitism and Holocaust denial are common in the Arab and Muslim worlds, claiming that the Holocaust is a Jewish hoax to legitimize Israel. ${ }^{48}$

Although attacks on Israel and antisemitic rhetoric from the political left have not changed significantly in recent decades, the situation on the political right mutated to a remarkable degree. That the far right shows public support for Israel and defends its statehood is the most significant change in recent years. Although in past decades classical antisemitic rhetoric and a hate of Israel normally went hand in hand, this is not automatically the case anymore. A number of examples spring to mind: In 2017, Donald Trump announced the moving of the US embassy from Tel Aviv to Jerusalem. This was a controversial decision given that East Jerusalem is still considered occupied territory according to the United Nations. Trump and his allies repeatedly echoed support for Israel and attacked Democrats in the United States as being antisemitic because of their criticisms of Israel. In a tweet in August 2019, the president quoted the conspiracist Wayne Allyn Root, who claimed that George Soros staged the events in Charlottesville. Root went on to say that the Israeli Jews love Trump "like he's the King of Israel. They love him like he is the second coming of God." 
Trump lost no time reposting this message on Twitter. The notion of a reborn Christian savior who returns to Israel echoes ancient beliefs about the role that Jews play in the ultimate triumph of Christianity. 49

The conservative evangelical Christians in the United States also support the return of Jews to Israel, because in their belief, it would hasten the second coming of Christ. In that event, of course, Jews would have to convert or perish. In other words, being pro-Israel does not always necessarily mean embracing and accepting Jews in their own right. ${ }^{\circ}$ Anti-Defamation League (ADL) director Jonathan Greenblatt found the references to Trump as the second "messiah" truly "breathtaking" and went on to say

that is the height of hypocrisy to use Christian theology to bully Jews and to push out some messianic [messaging]; literally it is hard to think about something less kosher [than] telling the Jewish people you are the King of Israel and therefore we should have some fidelity for some reason..$^{51}$

Messiah or not, Trump's support of Israel and repeated attacks on Muslims reflect the views of significant segments of religious Christians in the United States. Further, this first revision of pro-Israel sentiment that masks a true desire for Christian supremacy allows for the fostering of a second revision (and even erasure) of actual historical events.

Many white supremacist and neo-Nazi leaders are increasingly supporters of Israel. They support the state of Israel as a place where Jews can "go back where they came from" and leave white Christian societies alone. Some right-wing antisemites now point to "the solution of the Jewish question," arguing that their fellow citizens of Jewish background should be sent ("back") to Israel. The tendency to conflate Jews and Israelis insinuates that the real homeland for all Jews is Israel. In April 2019, Trump told American Jews that the prime minister of Israel is their leader..$^{2}$ These insinuations are reminiscent of classic antisemitic charges of dual loyalty or disloyalty of Jews used for almost 2000 years in Europe. 53

This phenomenon is not restricted to the United States. Far-right leaders in Europe and the United States repeatedly express support for Israel. The former head of the far-right Austrian Freedom Party, 
Heinz-Christian Strache, visited Israel and paid tribute to the Austrian victims at the Yad Vashem Holocaust Memorial in Jerusalem. ${ }^{54}$ But at the same time, right-wing leaders like him play into antisemitic tropes that argue that Jews are the masterminds behind the refugee crisis affecting Europe over the past few years. The right-wing leader talked about a "population shift" threatening the West, referring to conspiracy theories about white Christian Europeans being replaced by Muslims and people of color. Strache's party officials made headlines due to their antisemitic statements and language used while in power in Austria (as the junior partner in coalition with the conservative Austrian People's Party). 55

French right-wing populist Marine Le Pen has tried to detoxify her party by rejecting overt antisemitism while denying the role of the French State in the Holocaust. Poland's Law and Justice Party has put much effort into publicizing its "pro-Zionist" credentials, such as President Andrzej Duda's much-publicized 2017 visit to Israel's legendary officer Yoni Netanyahu's grave in Israel and his 2018 visit to the Warsaw Jewish cemetery, laying wreaths at the tombs of the Warsaw Uprising's last commander, Marek Edelman, and the commander of the Jewish Military Union, Pawel Frenkel. And yet Duda also publicly denies the full involvement of Poles during the wartime massacre at Jedwabne and has, as mentioned already in this chapter, signed the controversial "Holocaust law" that initially criminalized arguments blaming the Polish nation for co-responsibility for the Holocaust. There are, no doubt, many more examples of this new "ProIsrael and antisemitic" dilemma, as the Israel daily Haaretz put it in $2017.5^{56}$

These few examples show a discernible change in the type of antisemitism appearing in recent years. It is especially important because it shows that antisemitism may in some quarters be less blatant than its historical antecedents and yet be hidden in the superficial clothing of pro-Israeli sentiment. Importantly, this pro-Israelness is deceptive, and the same people/movements will simultaneously advance other forms of antisemitism. The question, though, is whether this "pro-Israel but antisemitic" view constitutes post-truth. Why does this seemingly contradictory view not provoke cognitive dissonance? Perhaps this pseudo-pro-Israeli rhetoric is directed at the feelings of European nationalists rather than at their reason. They see a politician 
visiting Israel or supporting Israel with words and feel that the politician cannot be antisemitic. And is there any reason why Duda visits the graves of Zionists and not Jewish-Polish anti-Zionist leaders, Orthodox Jews, or Polish-Jewish cultural figures? It seems to me that the choice of contemporary European nationalism venerating figures associated with Zionism (seen as Jewish nationalism) is not coincidental. Could the rationale constitute post-truth? Historically, nationalist and fascists movements (like Mussolini's) at times uttered support for Zionism. In the end, it was a mere tactic or practical move and not a change of heart of how they viewed Jews.

\section{Conclusion}

Antisemitism is one of the oldest hatreds and reasons for fake news. It has been around for almost 2000 years. Although the basic ideas of this hatred still lie at the core of what we observe, there have been changes in the post-truth era. Initially, the despising of Jews was based on religion and ultimately goes back to the Jewish view that Jesus was not the promised Messiah. For Christians, this was reason enough for the discrimination and persecution of their Jewish neighbors. In the 19th century, antisemitism became secularized, and religion was replaced by "race." Jews were then considered a separate race by many gentiles. The longest-living innovation was the conspiracy theory that Jews were constantly plotting to take over the world. In the post-truth world, this allegation is alive and well but adapted to current topics and issues. From the antisemitic perspective, Jews are behind the immigration of non-Europeans (non-white people) to the United States and other Western countries, behind feminism, behind the acceptance for LGBTQ communities, and behind pandemics. Ultimately, the Jews are accused of planning a "genocide" of white Christians by replacing and outnumbering them with non-Europeans.

These antisemitic conspiracy theories always needed a Jewish bogeyman, a face representing these dark forces allegedly at work. For antisemite and alt-right minds, this is George Soros. The Jewish Hungarian-American businessperson is blamed for almost everything: the refugee crisis in Europe, immigrant caravans in Central America, and the climate change "hoax." In this alternative "truth" of antisemitism, 
the Holocaust is often downplayed to a minor event if not denied directly. The demonization of Israel remains common and can be found in many political parties on the right and the left. Recently, many farright groups have attempted to make their brand more palatable by communicating a seemingly pro-Israel stance. While many of these trends are new variations on an old tune, the post-truth world is a world of mass media and the Internet. Distinguishing factual news from fake news is a challenge. The stakes are high in that fake news all too often leads to real hatred and even violence, as the events like the one in Pittsburgh have clearly demonstrated.

Acknowledgements If not stated otherwise, all the views and opinions expressed in this article are mine and do not necessarily reflect the views of the University of Nebraska-Lincoln. I thank Marius Gudonis, Benjamin T. Jones, Ari Kohen, Steven Wees, Robert Lipscomb, Mark Gudgel, Stas Nikolova, Anne Johnson, and other colleagues in the United States, Europe, and Australia for helping me write this piece.

\section{Notes}

1. Astor, "White Nationalists."

2. Astor, "Anti-Semitic Incidents."

3. Nelson, "Veterans."

4. Ruggles, "UNO."

5. Baker, "The Gunman at a California Garlic Festival."

6. Astor and Stevens, "Democrats Condemn Trump."

7. Lipstadt, Antisemitism: Here and Now, 53.

8. Anti-Defamation League, "Anti-Semitism."

9. Kaufmann, "Anti-Semitic Stereotypes in Zionism."

10. Porat, "Holocaust Denial," 468.

11. Bergen, War and Genocide, 3.

12. Wang, "'Post-truth' Named 2016 Word of the Year."

13. In Pingeot Mazarine's "Pour mieux saisir la post-verite, re-lire Hannah Arendt," from The Conversation France published online on 20 January 2017 (quoted in Gudonis, "How Useful is the Concept of Post-Truth," 146)

14. Lipstadt, Antisemitism, ix. On the most current developments in the United States, see also Weiss, Anti-semitism, 19.

15. For more on the "Jewish question" see Judaken, "Antisemitism and the Jewish Question.”

16. Efron et al., The Jews. See also Wistrich, Antisemitism, the Longest Hatred. 
17. See also the exhibition "A dangerous lie: The Protocols of the Elders of Zion," which opened in 2006 at the United States Holocaust Memorial Museum in Washington DC, accessed 2 September 2019, http://www.ushmm.org/information/exhibitions/museum-exhibitions/a-dangerous-lie-the-protocols-ofthe-elders-of-zion . For more on the history of anti-Semitism see Rosenfeld, Deciphering.

18. See more in Lipstadt, Denying, 41.

19. Bauer-Wolf, "Surge."

20. For more on this topic see Woeste, Henry Ford's War.

21. Hoare, "Move Over Soros"; See also Porat, "Holocaust Denial," 471.

22. Stern, "The Repackaging of Hate and Anti-Semitism in Our Post-Truth Era."

23. Tibon, "White House Disinvites Artist." The White House disinvited the cartoonist at the last minute after heavy criticism from American Jewish groups.

24. This imagery is all too familiar to antisemites, but they did not stop at hateful images and words. In October 2018, a pipe bomb was found in the mailbox of Soros's house in a New York suburb. Soros was one of 13 prominent Trump critics who were targeted by a domestic white terrorist. Swaine et al., "Florida man charged."

25. For Breitbart's articles about Soros, see http://www.breitbart.com/tag/georgesoros, accessed 3 September 2019.

26. See Karl Popper's influential book The Open Society and Its Enemies first published in two volumes in 1945.

27. Taschwer, "Die erste Vertreibung."

28. Lipstadt, Denying.

29. Lipstadt, Denying, xiii.

30. Porat, "Holocaust Denial," 472.

31. Lipstadt, Denying, 5.

32. Duke's most-recent and explicit comment on the Holocaust can be found on his radio show. In one episode, he states that the Red Cross inspected the camps and found no evidence of mass murder. Rense Radio Network, accessed 19 October 2019, http://renseradioarchives.com/archives/dduke/o82219.mp3

33. Lipstadt, Denying, 117. See also the British-American film Denial (2016).

34. Mayer, "A Conservative."

35. Amatulli, "Rep. Ted Lieu Plays Candace Owens' Hitler Remarks.” See also AntiDefamation League ADL website, "Turning Point USA," accessed 14 June 2019, http://www.adl.org/resources/backgrounders/turning-point-usa For the website of "Turning Point USA," see http://www.tpusa.com

36. Aderet, "'Orgy of Murder."

37. See, e.g., the Museum, "House of Terror in Budapest." Their website states, "Having survived two terror regimes, it was felt that the time had come for Hungary to erect a fitting memorial to the victims, and at the same time to present a picture of what life was like for Hungarians in those times." See http://www.terrorhaza.hulen accessed 14 September 2019. 
38. Porat, "Holocaust Denial," 479.

39. See more on recent trends in Rosenfeld, Hi Hitler.

40. Lipstadt, Denying, xi.

41. Rosenfeld, Hi Hitler, 7.

42. See also the German novel Eric-Emmanuel Schmitt, Adolf H.: Zwei Leben (Berne: Ammann 2008). Based on the idea of "Look who is back" there is also a 2018 Italian satirical comedy film about Benito Mussolini by the title "I am back" ("Sono tornato"). See "Lui è tornado."

43. Rosenfeld, The End, 2.

44. For more on this subject see Crim. Planet Auschwitz.

45. See also Marrus, Lessons.

46. Porat, "Holocaust Denial."

47. Lipstadt, Antisemitism, 171.

48. Kuentzel. “The Roots," 394.

49. McCarthy, “'I am the Chosen One’”

50. For more see Ariel, An Unusual Relationship.

51. "ADL CEO Jonathan Greenblatt."

52. Staff “Trump tells US Jews."

53. "ADL CEO Jonathan Greenblatt."

54. More on the recent history of the FPÖ see Reiter, Die Ehemaligen. See also Steinacher, "The Limits of Integration."

55. Gensing "Strache und der 'Bevolkerungsaustausch', On 27 January 2012, the international commemoration day for the liberation of Auschwitz - the Viennese right-wing student organizations orchestrated a highly controversial prom in Vienna. There had been a number of scuffles between the students and counter-protesters, and a few people were injured. Demonstrators outside the hall shouted “Nazis leave!” FPOE party leader Heinz-Christian Strache was reported to have said that the protests against the prom reminded him of the pogroms of November 1938 (Kristallnacht). He went on to say that "we [the right-wing activists] are the new Jews." For more, see Karner, "Multiple Dimensions and Discursive Contests in Austria's Mythscape," 193-210.

56. Pfeffer, "Pro-Israel and Anti-Semitic."

\section{Bibliography}

Aderet, Ofer. "'Orgy of Murder': The Poles Who 'Hunted' Jews and Turned Them Over to the Nazis." Haaretz, 11 February 2017. Accessed 14 October 2019. https://www.haaretz.com/world-news/.premium.MAGAZINE-orgy-of-murderthe-poles-who-hunted-jews-and-turned-them-in-1.5430977

“ADL CEO Jonathan Greenblatt on President Trump's 'Disloyalty' Tweet.” YouTube video, 5:35, featuring a CNN interview, posted by Anti-Defamation League, 21 August 2019. 
Amatulli, Jenna. “Rep. Ted Lieu Plays Candace Owens' Hitler Remarks During White Nationalism Hearing." Huffington Post, 10 April 2019.

Anti-Defamation League. “Anti-Semitism.” Accessed 1 July 2019. http://www.adl. org/anti-semitism

_. "Anti-Semitic Flyers in our Own Backyard." ADL Plains States/ CRC, 9 May 2018. Accessed 2 July 2019. https://omaha.adl.org/news/ anti-semitic-flyers-in-our-own-community/

Ariel, Yaakov. An Unusual Relationship: Evangelical Christians and Jews. New York and London: New York University Press, 2013.

Astor, Maggie. "Anti-Semitic Incidents Surged 57 Percent in 2017, Report Finds." New York Times, 27 February 2018. https://www.nytimes.com/2018/02/27/ us/anti-semitism-adl-report.html

—. "White Nationalists Want to March Again. Charlottesville Says No." in New York Times, 12 December 2017. Accessed: 1 July 2019. https://www.nytimes. com/2017/12/12/us/charlottesville-protest-permit-denied.html

Astor, Maggie, and Matt Stevens. "Democrats Condemn Trump After Shootings: This Week in the 2020 Race." New York Times, 10 August 2019. Accessed 19 October 2019. https://www.nytimes.com/2019/08/10/us/politics/2020democrats-trump-shootings.html

Baker, Sinead. "The Gunman at a California Garlic Festival Reportedly Referenced a White Supremacist Manifesto on Instagram before the Shooting." Insider, 30 July 2019. Accessed 19 October 2019. https://www.insider.com/ gilroy-garlic-festival-shooter-shared-neo-nazi-ideas-instagram-reports-2019-7

Bauer-Wolf, Jeremy. "A Surge of Anti-Semitism." Inside Higher Ed, 5 December 2018. www.insidehighered.comlnews/2018/12105/anti-semitic-incidentssurgecollege-campuses-after-pittsburgh-synagogue-shooting

Beirich, Heidi, "Rage against Change: White Supremacy Flourishes amid Fears of Immigration and Nation's Shifting Demographics." Intelligence Report, no. 166, Southern Poverty Law Center, Spring 2019.

Bergen, Doris. War and Genocide: A Concise History of the Holocaust. Lanham, MD: Rowman and Littlefield, 2016.

Crim, Brian. Planet Auschwitz: Holocaust Representation in Science Fiction and Horror. Rutgers University Press, 2020.

Efron, John, Matthias Lehmann, and Steven Weitzmann. The Jews: A History. New York: Routledge, 2019.

Feldman, Ari. "White Supremacist at University of Nebraska 'Poses Clear Threat to Minorities.” Forward, 14 February 2018.

Gensing, Patrick. "Strache und der Bevölkerimgsaustausch.” ARD, Tagesschau. de. Accessed 1 July 2019. http://www.tagesschau.de/faktenfinder/ bevoelkerungsaustauschstrache-101.html

Gudonis, Marius. "How Useful is the Concept of Post-Truth in Analysing Genocide Denial? Analysis of Online Comments on the Jedwabne Massacre." Zoon Politikon 8 (2017). https://doi.org/10.4467/2543408XZOP.17.006.9265 
Hayden, Michael Edison. "Nebraska White Supremacist who Praises Violence Poses Unique Challenges to Campus Free Speech.” Newsweek, 13 February 2018.

Hoare, Liam. "Move Over Soros: Meet the Anti-Semites' New 'Dirty', 'All-powerful' Jewish Bogeyman.” Haaretz, 26 May 2019. Accessed 1 July 2019. https://www. haaretz.com/world-news/.premium-move-over-soros-meet-the-anti-semitesnew-all-powerful-jewish-bogeyman-1.7286028

Judaken, Jonathan. "Antisemitism and the Jewish Question." Chap. 20 in The Cambridge History of Judaism: Vol. 8: The Modern World 1815-2000, edited by Michael B. Hart and Tony Michels, 559-588. Cambridge: Cambridge University Press, 2017.

Karner, Christian. "Multiple Dimensions and Discursive Contests in Austria's Mythscape." In The Use and Abuse of Memory: Interpreting World War II in Contemporary European Politics, edited by Christian Karner and Bram Mertens. New Brunswick: Transaction Publishers, 2013.

Kaufmann, Yehezkel. "Anti-Semitic Stereotypes in Zionism: The Nationalist Rejection of Diaspora Jewry." Translated by Jacob Sloan. Commentary, March 1949 [originally published in Be-Havle Ha-Zeman, Tel Aviv, 1936]. http://www. commentarymagazine.com/articles/anti-semitic-stereotypes-in-zionism- thenationalist-rejection-of-diaspora-jewry/

Kohen, Ari, and Gerald J. Steinacher, eds. Antisemitism: From the 1930s to Today: Contemporary Holocaust Studies - Vol. 2. Lincoln: University of Nebraska Press, 2021.

Kuentzel, Matthias. "The Roots of Antisemitism in the Middle East: New Debates." In Resurgent Antisemitism: Global Perspectives, edited by Alvin H. Rosenfeld, 382-401. Bloomington: Indiana University Press, 2013.

Lipstadt, Deborah. Antisemitism: Here and Now. Melbourne: Scribe, 2019.

- Denying the Holocaust: The Growing Assault on Truth and Memory. New York: Free Press, 1993.

"Lui è tomato vs Sono tornado." YouTube video, 25:15, posted by "Mortebianca," 27 May 2018. http://www.youtube.com/watch?v=gHUOYSTwkxo

Marrus, Michael R. Lessons of the Holocaust. Toronto: University of Toronto Press, 2016.

McCarthy, Tom. "'I am the Chosen One': With Boasts and Insults, Trump Sets New Benchmark for Incoherence." The Guardian, 21 August 2019. Accessed 19 October 2019. http://www.theguardian.com/us-news/2019/aug/21/ trump-press-conference-greenland-jewish-democrats

Mayer, Jane. "A Conservative Nonprofit That Seeks to Transform College Campuses Faces Allegations of Racial Bias and Illegal Campaign Activity." The New Yorker, 21 December 2017.

Nelson, Andrew J. "Veterans Cover Swastika Site with US Flag and Recite the Pledge.” Omaha World Herald, 28 July 2018. 
Pfeffer, Anshel, "Pro-Israel and Anti-Semitic: Israel's Dilemma with the European Far-Right.” Haaretz, 16 March 2017. Accessed 16 October 2019. http://www. haaretz.com/israel-news/.premium-pro-israel-anti-semitic-israel-s-europeanfar-right-dilemma-1.5449254

Porat, Dina. "Holocaust Denial and the Image of the Jew, or 'They Boycott Auschwitz as an Israeli Product." In Resurgent Antisemitism: Global Perspectives, edited by Alvin H. Rosenfeld, 468-481. Bloomington: Indiana University Press, 2013.

Reiter, Margit. Die Ehemaligen. Der Nationalsozialismus und die Anfange der FPÖ. Göttingen: Wallstein, 2019.

Reitman, Janet. "How Law Enforcement Failed to See the Rise of White Nationalism.” New York Times Magazine, 4 November 2018.

Rosenfeld, Alvin H., ed. Deciphering the New Antisemitism. Bloomington: Indiana University Press, 2015.

Rosenfeld, Gavriel D. Hi Hitler! How the Nazi Past is being Normalized in Contemporary Culture. Cambridge: Cambridge University Press, 2015.

Rossman-Benjamin, Tammi. "Academic BDS and the Calculus of Hypocrisy." Inside Higher Ed, 20 March 2019. Accessed 14 September 2019. http://www.insidehighered.com/views/2019/03/20/ scholars-who-support-bds-are-denying-academic-freedom-students-opinion

Ruggles, Rick. "UNO Finds Swastika, 'Make America Great Again' Carved into Bathroom Wall." Omaha World Herald, 5 December 2016.

Serwer, Adam. "White Nationalism's Deep American Roots." The Atlantic, April 2019. Accessed 1 July 2019. http://www.theatlantic.com/magazine/ archive/2019/04/adam-serwer-madison-grant-white-nationalism/583258/

Steinacher, Gerald J. "The Limits of Integration: Nazi officials and their New Political Careers after 1945 in West-Germany and Austria." In After Nazism: Relaunching Careers in Germany and Austria, edited by Susanna Schrafstetter and Jürgen Zarusky. (German Yearbook of Contemporary History - Vol. 5). Lincoln: University of Nebraska Press, 2020.

Stern, Alexandra Minna. "The Repackaging of Hate and Anti-Semitism in Our Post-Truth Era.” 31 October 2018. Accessed 15 October 2019. http://www. beaconbroadside.com/broadside/2018/10/the-repackaging-of-hate-and-antisemitism-in-our-post-truth-era.html

Swaine, Jon, Erin Durkin, and Richard Luscombe. "Florida Man Charged with Sending 13 Pipe Bombs to Trump Critics." The Guardian, 27 October 2018. http://www.theguardian.com/us-news/2018/oct/26/ suspicious-package-pipe-bombs-latest-found-cory-booker-florida

Taschwer, Klaus. "Die erste Vertreibung einer Universität in der Europäischen Union.” Der Standard, 2 August 2019.

Tibon, Amir. "White House Disinvites Artist Who Drew 'Blatantly anti-Semitic' Cartoon.” Haaretz, 11 July 2019. Accessed 15 October 2019. http://www. haaretz.com/us-news/white-house-disinvites-artist-who-drew-blatantly-antisemitic-cartoon-following-backlash-1.7487669 
Times of Israel and AP staff. "Trump Tells US Jews that Netanyahu is 'Your Prime Minister'” Times of Israel, 7 April 2019. Accessed 19 October 2019. http://www. timesofisrael.com/trump-tells-us-jews-that-netanyahu-is-your-prime-minister/

Wang, Amy B. "'Post-Truth' Named 2016 Word of the Year by Oxford Dictionaries." Washington Post, 16 November 2016. Accessed 19 October 2019. http://www.washingtonpost.com/news/the-fix/wp/2016/11116/ post-truth-named-2016-word-of-the-year-by-oxford-dictionaries/

Weiss, Bari. How to Fight Anti-Semitism. New York: Crown, 2019.

Wistrich, Robert S. Antisemitism, the Longest Hatred. New York, Pantheon, 1992.

Woeste, Victoria Saker. Henry Ford's War on Jews and the Legal Battle against Hate Speech. Stanford: Stanford University Press, 2012. 